\title{
Immunohistochemical analysis of bcl-2 expression in transitional cell carcinoma of the bladder
}

\author{
H Shiina, M Igawa, S Urakami, S Honda, H Shirakawa, T Ishibe
}

\begin{abstract}
Aims-To evaluate the expression of bcl2 in transitional cell carcinoma (TCC) of the bladder; to compare bcl-2 expression with clinicopathological findings, p53 immunoreactivity, proliferating cell nuclear antigen (PCNA) expression, 2c deviation index (2cDI), 5c exceeding rate (5cER), and the mean nuclear area (MNA).

Methods-Cystectomy specimens from 77 patients with untreated, non-metastatic TCC of the bladder were studied. Expression of bcl-2, p53 and PCNA was detected immunohistochemically using the following monoclonal antibodies: bcl-2/ 124, DO-7 and PC10, respectively. Nuclear DNA content was analysed using static cytometry.
\end{abstract}

Results-Bcl-2 was expressed in 19 (24.7\%) of 77 TCCs and in $74(96 \cdot 1 \%)$ of 77 normal samples of transitional epithelium (taken from normal tissue adjacent to the tumour in each case). In all cases, bcl-2 immunoreactivity was more intense in normal transitional epithelium than in TCC. In normal transitional epithelium and superficial TCC bcl-2 immunoreactivity was observed at the basal layer, and not at the invasive front. Bcl-2 immunoreactivity was inversely correlated with histological grade and p53 immunoreactivity, and was not correlated with the pT category, disease progression, PCNA expression, 2cDI, $5 \mathrm{cER}$, and the MNA. No significant correlation was found between bcl-2 expression and overall survival.

Conclusions-Bcl-2 expression in TCC of the bladder seems to be associated with a less aggressive phenotype and does not play an important role in tumour progression.

(F Clin Pathol 1996;49:395-399)

Keywords: Bcl-2, p53, PCNA, immunohistochemistry, bladder cancer, DNA content.

Department of Urology, Shimane Medical University, 89-1 Enya-cho Izumo 693, Japan

H Shiina

M Igawa

$S$ Urakami

$S$ Honda

H Shirakawa

T Ishibe

Correspondence to: Dr Hiroaki Shiina.

Accepted for publication 9 September 1995

The B cell leukaemia/lymphoma 2 gene (bcl2) product is an inner mitochondrial membrane protein that inhibits programmed cell death (apoptosis), ${ }^{1}$ thus bestowing a survival advantage on cells expressing this oncoprotein. $\mathrm{Bcl}-2$ positive cells may then undergo a secondary event, rendering them susceptible to malignant transformation. ${ }^{2}$ The bcl-2 gene product has been intensively investigated in haematological malignancies, where over- production of both bcl- 2 mRNA and protein has been associated with a $14 ; 18$ chromosomal translocation. ${ }^{3}$ Recently, bcl-2 expression has been reported in several non-haematopoietic tumours, such as small cell and non-small cell carcinomas of the $\operatorname{lung}^{45}$ and melanocytic tumours, ${ }^{6}$ suggesting that the $14 ; 18$ translocation is not always required for the production of an immunohistochemically detectable bcl-2 protein. Bcl-2 immunoexpression has also been demonstrated in glandular epithelium of hormone and growth factor regulating tissues, such as prostate, ${ }^{7}$ breast $^{8}$ and thyroid, ${ }^{9}$ as well as in epithelium containing longlived stem cells, such as the intestine. ${ }^{10} \mathrm{As}$ there have been no reports regarding bcl-2 immunoreactivity in transitional cell carcinoma (TCC) of the bladder, the functional role of bcl-2 in this tumour remains unclear.

The $\mathrm{p} 53$ protein is a nuclear phosphoprotein regulating cell growth at the G1/S checkpoint. It is a tumour suppressor gene $\mathrm{e}^{112}$ and plays an important role in eliminating cells with damaged DNA by inducing apoptosis. ${ }^{13}$ p53 gene mutations are the most common genetic alterations in human cancers, ${ }^{12}$ leading to the inhibition of DNA surveillance and repair and thereby increasing the risk of other gene mutations and chromosomal rearrangements. ${ }^{13}$ Thus, p53 gene mutations are associated with carcinogenesis and tumour progression. ${ }^{14}$

The aim of this study was to elucidate the functional role of bcl-2 in TCC of the bladder using archival paraffin wax embedded tissue specimens and to compare bcl-2 expression with clinicopathological findings, p53 immunoreactivity, expression of the proliferating cell nuclear antigen (PCNA), ${ }^{1516}$ and DNA parameters such as the $2 \mathrm{c}$ deviation index $(2 \mathrm{cDI}),{ }^{1718}$ the $5 \mathrm{c}$ exceeding rate $(5 \mathrm{cER})^{1718}$ and the mean nuclear area (MNA).

\section{Methods}

Radical cystectomy specimens from 77 patients (19 women and 58 men) with untreated, nonmetastatic TCC of the bladder were studied. The mean age of the patients at surgery was $62 \cdot 3$ years (range $37-81$ years). Mean follow up was $45 \cdot 3$ months (range 19-135 months). Tumours were staged according to the UICC system. ${ }^{19}$ Disease progression was defined as an increase in the $\mathrm{N}$ or $\mathrm{M}$, or both, categories during follow up. Patients who died of disease other than bladder cancer were excluded from the study. After surgery, patients with TCC of high histological grade (more than grade II) or 
Table 1 Histological grade and stage

\begin{tabular}{llccl}
\hline & Grade I & Grade II & Grade III & Total \\
\hline pTa & 4 & 9 & 0 & 13 \\
pT1 & 3 & 15 & 3 & 21 \\
? pT2 & 1 & 16 & 26 & 43 \\
Total & 8 & 40 & 29 & 77 \\
\hline
\end{tabular}

high histological stage (more than pT2), or both, were treated with adjuvant chemotherapy comprising cisplatin, cyclophosphamide and adriamycin.

Tumour tissue and adjacent normal tissue specimens were fixed in $10 \%$ buffered formalin ( $\mathrm{pH} \mathrm{7.0)}$ for 24-30 hours and embedded in paraffin wax. Five consecutive sections, $5 \mu \mathrm{m}$ thick, were cut from each block and mounted
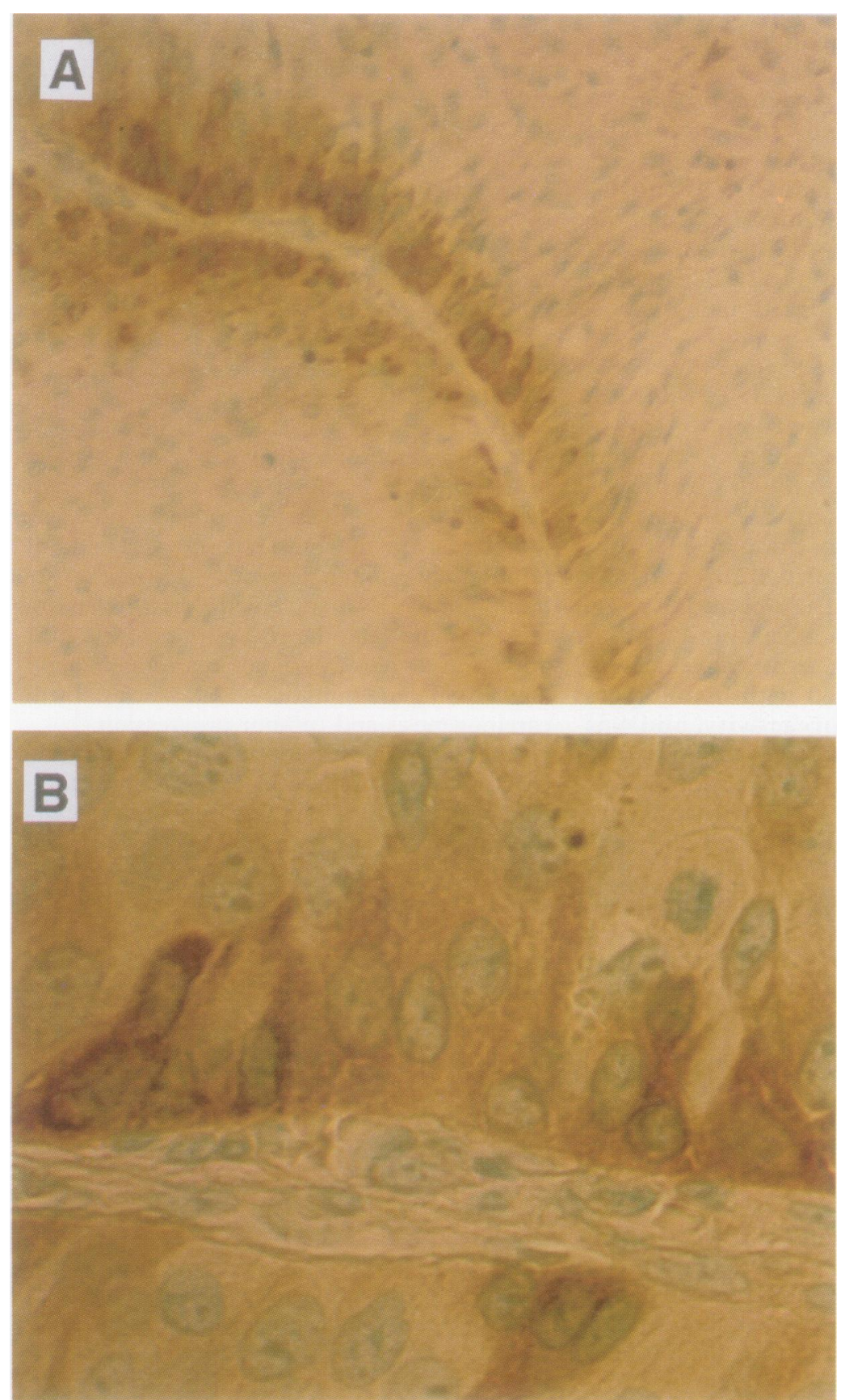

Figure 1 Immunoexpression of bcl-2 in superficial, grade I TCC $(A, \times 200 ; B, \times 400$; methyl green counterstain). Note the predominant distribution of cells with bcl-2 immunoreactivity near the basement membrane. Bcl-2 immunoreactivity is not present at the superficial differentiating layer. on poly-1-lysine coated slides. One of the five sections was stained with haematoxylin and eosin for histological evaluation, was independently reviewed by two pathologists and graded as recommended by the World Health Organisation (WHO). ${ }^{20}$ The pT category of each TCC was assigned by examination of two or three representative sections in each case, as $\mathrm{pTa}, \mathrm{pT} 1, \mathrm{pT} 2$, and $>\mathrm{pT} 2$. The histological findings are summarised in table 1. Multicentric tumour formation was observed in the bladders of all seven patients with grade I superficial TCC.

\section{BCL-2 IMMUNOSTAINING}

Sections were deparaffinised routinely and were pretreated in a microwave at $700 \mathrm{~W}$ in $10 \mathrm{mM}$ citrate buffer $(\mathrm{pH} 6 \cdot 0)$ for five minutes. They were then allowed to cool for five minutes, re-microwaved and placed slowly in distilled water. Endogenous peroxidase activity was blocked by incubating the slides in 3\% hydrogen peroxide for 30 minutes. The slides were washed in $0.05 \mathrm{M}$ Tris buffer ( $\mathrm{pH} \mathrm{7.6)}$ and incubated in $2 \%$ bovine serum albumin for 10 minutes and were then incubated for 12 hours at room temperature with a monoclonal antibody directed against bcl-2 (bcl-2, clone 124; Dako, Carpinteria, California, USA), diluted 1 in 50 in $0.05 \mathrm{M}$ Tris buffer. After which, the slides were washed three times in Tris buffer and bcl-2 immunostaining was detected using the LSAB kit, as recommended by the manufacturer (Dako) with diaminobenzidine as the chromogen. The sections were counterstained with $0.5 \%$ methyl green. As a negative control, specific primary monoclonal antibody was replaced by the immunoglobulin fraction of nonimmune mouse serum. Normal lymphocytes served as a positive control.

\section{PCNA AND P53 IMMUNOSTAINING}

Expression of p53 was detected immunohistochemically using a mouse anti-p 53 monoclonal antibody (DO-7) (Dako) as described for bcl2. Sections obtained from a patient with $\mathrm{pT} 3 \mathrm{~b}$ GIII exhibiting intense p53 positive staining served as a positive control. PCNA expression was detected in routinely processed, rehydrated sections by using a mouse monoclonal antiPCNA antibody (PC10) (Dako). Non-immune mouse IgG replaced specific primary antibody in the negative control. Normal human tonsil served as a positive control.

\section{EVALUATION OF IMMUNOSTAINING}

$\mathrm{Bcl}-2$ immunostaining was scored as the percentage of cells exhibiting definite immunoreactivity in at least 2000 neoplastic cells encountered in 20 randomly selected high power fields $(\times 400)$. A specimen was regarded as positive when more than $10 \%$ of the neoplastic cells exhibited bcl-2 immunoreactivity. p53 immunoreactivity and PCNA expression were evaluated using the Quantitative ER/PR Analysis software in the CAS 200 image analyser (Cell Analysis Systems, Elmhurst, Illinois, 

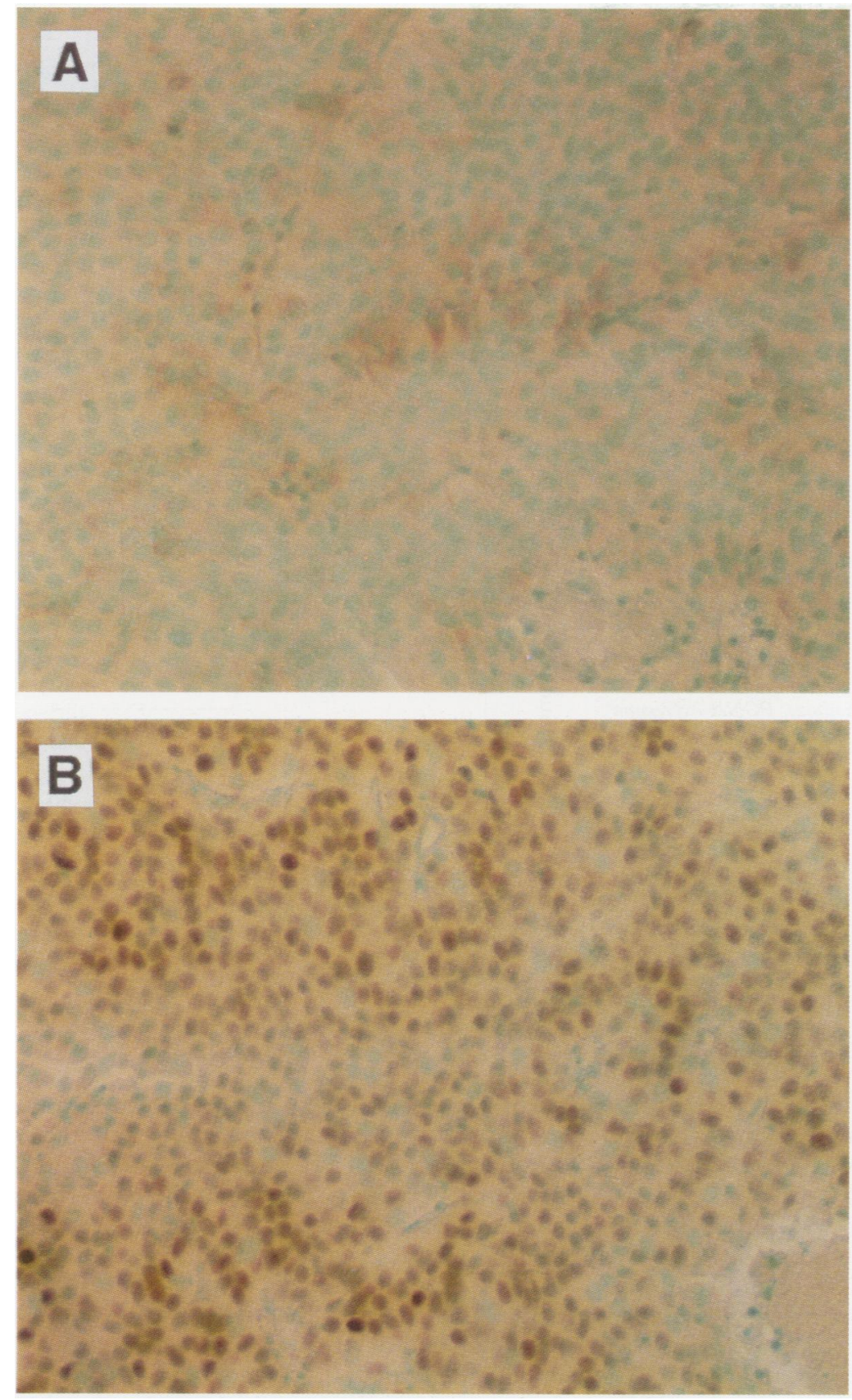

Figure 2 Immunoexpression of bcl-2 (A) and p53 (B) in invasive, grade III TCC $(\times 200$, methyl green counterstain). Note the scanty distribution of cells with bcl-2 immunoreactivity, and the diffuse distribution of cells with strong p53 immunoreactivity.

USA) and were expressed as the per cent positive rate and per cent positive intensity. ${ }^{21}$ The positive rate was expressed as the mean percentage of neoplastic cells exhibiting positive immunostaining against the total number of neoplastic cells encountered in 20 randomly selected high power fields. Intensity was also represented as the mean percentage of intensity against the intensity observed in positive controls. The areas analysed for bcl-2, p53 and PCNA immunostaining were the same as those evaluated histologically.

MEASUREMENT OF DNA CONTENT

The $5 \mu \mathrm{m}$ thick sections were dewaxed in xylene and rehydrated in decreasing concentrations of ethanol. The sections were then stained with Feulgen reagent using the Quantitative DNA staining kit (Cell Analysis Systems). The slides were analysed using the Cell Measurement Program software in the CAS 200 Image Analysis System. Incomplete and blurred nuclei were not evaluated. At least 250 well preserved nuclei were evaluated in each section. The DNA content of the cell at G0/G1 phase was defined as $7 \cdot 18 \mathrm{pg}$ using a DNA calibration slide supplied by the CAS 200 Image Analysis System. The DNA content of each cell was calculated using the following formula: DNA content $=667 \cdot 74 \times$ optical density $(O D) /$ peak $\mathrm{OD} / 7 \cdot 18$, where the peak OD was obtained from the control slide in each case. The $2 \mathrm{cDI}$ was calculated as the sum of squares of the differences between the DNA values of single cells (ci) and the $2 \mathrm{c}$ value, divided by the numbers of measured cells (n) $[2 \mathrm{cDI}=\mathrm{S}$ (ci$2 \mathrm{c}) 2 \times 1 / \mathrm{n}] .^{1718}$ The $5 \mathrm{cER}$ was defined as the percentage of cells with aneuploid nuclear DNA content over $5 \mathrm{c}$ that was not an exponent of $2 .{ }^{1718}$ The areas analysed for nuclear DNA content were the same as those evaluated histologically.

\section{STATISTICAL ANALYSIS}

All numerical data were expressed as mean (SD). The relation between bcl-2 immunoreactivity and the clinicopathological findings was evaluated statistically using the $\chi^{2}$ test. The relation between bcl-2 expression and p53 immunoreactivity, PCNA expression, 2cDI, $5 \mathrm{cER}$, and the MNA was analysed using the unpaired Wilcoxon test. To evaluate prognostic relevance, survival was computed from the time of surgery until death or date of last follow up. The Kaplan-Meier method was used for univariate analysis and the log rank test was used to assess differences between groups. A p value below 0.05 was regarded as statistically significant.

\section{Results}

\section{BCL-2 IMMUNOSTAINING}

Bcl-2 immunostaining was typically cytoplasmic. In normal transitional epithelium and superficial TCC bcl-2 immunoreactivity was observed at the basal layer, and not at the leading edge of the tumour (figs $1 \mathrm{~A}$ and $1 \mathrm{~B}$ ). In invasive TCC, however, bcl-2 positive cells were rarely observed (fig $2 \mathrm{~A}$ ), p53 positive cells were diffusely distributed (fig 2B), and were rarely seen at the leading edge.

\section{BCL-2 EXPRESSION IN RELATION TO}

CLINICOPATHOLOGICAL FINDINGS (TABLE 2)

$\mathrm{Bcl}-2$ was expressed in $19(24 \cdot 7 \%)$ of 77 TCCs and in $74(96 \cdot 1 \%)$ of 77 normal samples of transitional epithelium. In all cases, bcl-2 immunoreactivity was more intense in normal transitional epithelium than in TCC. Bcl-2 immunoreactivity was inversely correlated with histological grade $(p<0.05)$ and was not correlated with gender distribution, the pT category, disease progression, and prognosis. 
Table 2 Bcl-2 immunoreactivity in relation to clinicopathological findings

\begin{tabular}{|c|c|c|c|c|}
\hline Clinicopathological findings & $n$ & \multicolumn{2}{|c|}{ Bcl-2 positivity (n (\%)) } & $p$ value ( $\chi^{2}$ test $)$ \\
\hline $\begin{array}{l}\text { normal transitional epithelium } \\
\text { TCC }\end{array}$ & $\begin{array}{l}77 \\
77\end{array}$ & $\begin{array}{l}74 \\
19\end{array}$ & $\begin{array}{l}(96 \cdot 1 \%) \\
(24 \cdot 7 \%)\end{array}$ & $\mathrm{p}<0.001$ \\
\hline $\begin{array}{l}\text { Sex } \\
\text { male } \\
\text { female }\end{array}$ & $\begin{array}{l}58 \\
19\end{array}$ & $\begin{array}{r}15 \\
4\end{array}$ & $\begin{array}{l}(25 \cdot 9 \%) \\
(21 \cdot 1 \%)\end{array}$ & NS \\
\hline $\begin{array}{l}\text { Age } \\
\quad \geq 63 \text { years } \\
<63 \text { years }\end{array}$ & $\begin{array}{l}49 \\
28\end{array}$ & $\begin{array}{r}13 \\
6\end{array}$ & $\begin{array}{l}(26 \cdot 5 \%) \\
(21 \cdot 4 \%)\end{array}$ & NS \\
\hline $\begin{array}{l}\text { Histological grade } \\
\text { I } \\
\text { II } \\
\text { III }\end{array}$ & $\begin{array}{r}8 \\
40 \\
29\end{array}$ & $\begin{array}{l}5 \\
8 \\
6\end{array}$ & $\begin{array}{l}(62 \cdot 5 \%) \\
(20 \cdot 0 \%) \\
(20 \cdot 6 \%)\end{array}$ & $\mathrm{p}<0.05$ \\
\hline $\begin{array}{l}\text { pT category } \\
\text { pTa } \\
\text { pT1 } \\
\geqslant \text { pT2 }\end{array}$ & $\begin{array}{l}13 \\
21 \\
43\end{array}$ & $\begin{array}{r}5 \\
4 \\
10\end{array}$ & $\begin{array}{l}(38 \cdot 5 \%) \\
(19 \cdot 0 \%) \\
(23 \cdot 2 \%)\end{array}$ & NS \\
\hline $\begin{array}{l}\text { Disease progression } \\
\text { no } \\
\text { yes }\end{array}$ & $\begin{array}{l}43 \\
34\end{array}$ & $\begin{array}{r}14 \\
5\end{array}$ & $\begin{array}{l}(32 \cdot 5 \%) \\
(14 \cdot 7 \%)\end{array}$ & NS \\
\hline $\begin{array}{l}\text { Prognosis } \\
\text { alive } \\
\text { dead }\end{array}$ & $\begin{array}{l}45 \\
32\end{array}$ & $\begin{array}{r}14 \\
5\end{array}$ & $\begin{array}{l}(31 \cdot 1 \%) \\
(15 \cdot 6 \%)\end{array}$ & NS \\
\hline
\end{tabular}

$\mathrm{n}=$ Number of patients.

Table 3 Bcl-2 immunoreactivity in relation to $p 53$ immunoreactivity, PCNA expression $2 c D I, 5 c E R$, and mean nuclear area

\begin{tabular}{|c|c|c|c|}
\hline & \multicolumn{2}{|c|}{ Bcl-2 immunoreactivity } & \multirow[b]{2}{*}{$p$ value } \\
\hline & Negative $(n=58)$ & Positive $(n=19)$ & \\
\hline $\begin{array}{l}\text { p53 immunoreactivity } \\
\% \text { positive rate } \\
\% \text { positive intensity }\end{array}$ & $\begin{array}{l}24 \cdot 5 \pm 28 \cdot 0 \\
41 \cdot 3 \pm 34 \cdot 1\end{array}$ & $\begin{array}{l}7 \cdot 85 \pm 15 \cdot 4 \\
16 \cdot 2 \pm 21 \cdot 7\end{array}$ & $\begin{array}{l}\mathrm{p}<0.01 \\
\mathrm{p}<0.01\end{array}$ \\
\hline $\begin{array}{l}\text { PCNA expression } \\
\% \text { positive rate } \\
\% \text { positive intensity }\end{array}$ & $\begin{array}{l}24 \cdot 8 \pm 14 \cdot 7 \\
42 \cdot 7 \pm 19 \cdot 8\end{array}$ & $\begin{array}{l}20 \cdot 7 \pm 14 \cdot 9 \\
35 \cdot 9 \pm 21 \cdot 9\end{array}$ & $\begin{array}{l}\text { NS } \\
\text { NS }\end{array}$ \\
\hline $2 \mathrm{cDI}$ & $0 \cdot 95 \pm 1 \cdot 22$ & $0.64 \pm 0.75$ & NS \\
\hline $5 \mathrm{cER}(\%)$ & $9 \cdot 54 \pm 11 \cdot 8$ & $5 \cdot 95 \pm 7 \cdot 34$ & NS \\
\hline Mean nuclear area $\left(\mu \mathrm{m}^{2}\right)$ & $59 \cdot 6 \pm 22 \cdot 2$ & $54 \cdot 5 \pm 15 \cdot 3$ & NS \\
\hline
\end{tabular}

BCL-2 IMMUNOREACTIVITY IN RELATION TO P53 IMMUNOREACTIVITY, PCNA EXPRESSION, 2CDI, 5CER, AND MNA (TABLE 3)

Bcl-2 immunoreactivity was inversely correlated with p53 immunoreactivity and was not correlated with PCNA expression. p53 immunostaining was observed in $39(50.6 \%)$ of the 77 TCCs $(>10 \%$ cells positive in each case). The $2 \mathrm{cDI}$ and $5 \mathrm{cER}$ were lower in bcl2 positive compared with bcl- 2 negative TCCs, but this difference did not reach statistical significance. The difference in the MNA between bcl-2 positive and negative TCCs also did not reach statistical significance.

BCL-2 EXPRESSION AND P53

IMMUNOREACTIVITY IN RELATION TO SURVIVAL (FIGS 3A AND 3B)

Using univariate analysis, there was no significant difference in survival rate between patients with bcl-2 positive and negative TCC. Patients with p53 positive TCC had a significantly worse clinical outcome compared with those with p53 negative TCC.

\section{Discussion}

Bcl-2 immunoexpression has been demonstrated in glandular epithelium of hormone and growth factor regulating tissues, such as prostate, ${ }^{7}$ breast $^{8}$ and thyroid, ${ }^{9}$ as well as in epithelium containing longlived stem cells,
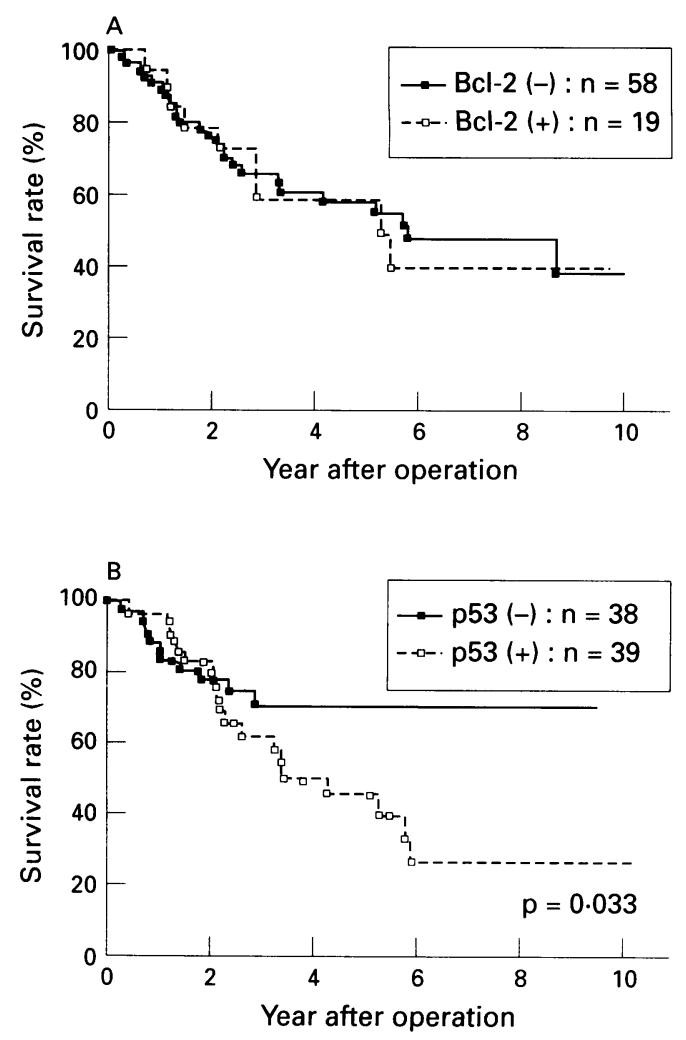

Figure 3 Survival rate based on bcl-2 (A) and p53 (B) immunostaining. There was no significant difference in the survival rate between bcl-2 positive and negative TCCs $(p=0.821)$; however, there was a significant difference in survival rates between $p 53$ positive and negative TCCs $(p=0.033)$.

such as the intestine..$^{10}$ In the present study, in normal transitional epithelium and most superficial TCCs (pTa and grade I) bcl-2 immunoreactivity was observed at the basal layer and not in the upper differentiated layers of the epithelium. The characteristic distribution of bcl-2 immunoreactivity in transitional epithelium suggests that bcl-2 expression is present in undifferentiated cells undergoing terminal differentiation, which require protection from apoptosis. In most high grade, invasive TCCs bcl-2 immunoreactivity was not observed at the leading edge of the tumour and was inversely correlated with histological grade. These findings suggest that bcl-2 immunoreactivity is associated with a less aggressive TCC phenotype.

Bcl-2 immunoreactivity did not correlate significantly with cell proliferation (PCNA expression). But, bcl-2 may promote cell survival even when the cells are not proliferating and the part played by bcl- 2 in the control of cell proliferation during disease progression, as has been found in some solid tumours, ${ }^{5922}$ seems to be less important in TCC of the bladder.

Accumulation of p53 protein as a result of mutations in the p53 gene is associated with carcinogenesis and tumour progression, ${ }^{23}$ and potentially has an inhibitory effect on apoptosis. ${ }^{24}$ There is an inverse correlation between p53 and bcl-2 immunoexpression in some solid tumours. ${ }^{58922}$ In the present study p53 immunoreactivity was significantly associated with clinical outcome, whereas bcl-2 expression 
was not, suggesting that bcl-2 does not prolong cell survival in the transitional epithelium, with the associated risk of malignant transformation, and does not contribute to tumour progression in TCC of the bladder.

Cell proliferation is closely correlated with recurrence, invasion, metastasis, and prognosis in TCC of the bladder. ${ }^{25-27}$ Hemstreet et a ${ }^{28}$ reported that the most important predictors of death and recurrence, respectively, in TCC of the bladder are stem line aneuploidy and the presence of cells with greater than 5c DNA. In the present study, we found no correlation between bcl-2 expression and indicators of genetic instability ( $5 \mathrm{cER}$ and $2 \mathrm{cDI}$ ), suggesting that expression of bcl-2 has no effect on the behaviour of tumour cells in TCC of the bladder. Recently, Lipponen and Aaltomaa ${ }^{29}$ reported that apoptosis, evaluated by light microscopy and expressed as the number of apoptotic cells $/ \mathrm{mm}^{2}$ of neoplastic epithelium (apoptotic index), was independently related to recurrence-free survival in patients with superficial TCC of the bladder, but had no prognostic significance overall. Our results are very similar to those reported by Lipponen and Aaltomaa. We found no correlation between apoptosis, as evaluated by bcl- 2 expression, and prognosis, and a strong correlation between bcl-2 expression and superficial TCC. In conclusion, bcl-2 expression in TCC of the bladder seems to be associated with a less aggressive phenotype and does not play an important role in tumour progression.

1 Hockenbery D, Nunez G, Milliman C, Schreiber RD, Korsmeyer SJ. Bcl-2 is an inner mitochondorial membrane protein that blocks programmed cell death. Nature 1990; 348:334-6.

2 Korsmeyer SJ. Bcl-2 initiates a new category of oncogenes: regulators of cell death. Blood 1992;80:879-86.

3 Tsujimoto Y, Croce CM. Analysis of the structure, transcripts and protein products of bcl-2, the gene involved scripts and protein products of bcl-2, the gene involved in human follicular

4 Ben-Ezra JM, Kornstein MJ, Grimes MM, Krystal G. Small cell carcinomas of the lung express the Bcl-2 protein. $A m$ f Pathol 1994;145:1036-40.

5 Fontanini G, Vignati S, Bigni D, Mussi A, Lucchi M, Angeletti CA, Basolo F, Bevilacqua G. Bcl-2 protein: prognostic factor inversely correlated to $\mathrm{p} 53$ in non-smallcell lung cancer. Br $\mathcal{F}$ Cancer 1995;71:1003-7.

6 van den Oord JJ, Vandeghinste $N$, de Ley $M$, de Wolf Peeters C. Bcl-2 expression in human melanocytes and melanocytic tumors. Am $\mathcal{F}$ Pathol 1994;145:294-300.

7 McDonnell TJ, Troncoso P, Brisbay SM, Logothetis C, Chung LWK, Hsieh J-T, et al. Expression of the protooncogene bcl-2 in the prostate and its association with emergence of androgen-independent prostate cancer. Cancer Res 1992;52:6940-4.

8 Bhargava V, Kell DL, van den Rijn M, Warnke RA. Bcl2 immunoreactivity in breast carcinoma correlates with 2 immunoreactivity in breast carcinoma correlates with
hormone receptor positivity. Am $\mathcal{F}$ Pathol 1994;145:53540.

9 Pilotti S, Collini O, Rilke F, Cattoretti G, Bo RD, Pierotti MA. Bcl-2 protein expression in carcinomas originating from the follicular epithelium of the thyroid gland. $\mathcal{F}$ Pathol 1994;172:337-42.

10 Hockenbery DM, Zutter M, Hickey W, Nahm M, Korsmeyer SJ. Bcl-2 protein is topographically restricted in tissues characterized by apoptotic cell death. Proc Nat Acad Sci USA 1991;88:6961-5.

11 Levine AL, Momand J, Finlay CA. The p53 tumor suppressor gene. Nature 1991;351:453-6.

12 Finlay CA, Hinds PW, Levine AJ. The p 53 proto-oncogene can act as a suppressor of transformation. Cell 1989;57: 1083-93.

13 Lane DP. p53, guardian of the genome. Nature 1992;358: 15-16.

14 Hollstein M, Sidransky D, Vogelstein B, Harris C. p53 mutations in human cancers. Science 1991;253:49-53.

15 Waseem NH, Lane DP. Monoclonal antibody analysis of the proliferating cell nuclear antigen (PCNA). Structura conservation and the detection of a nucleolar form. $\mathcal{F ~ C e l l ~}$ Sci 1990;96:121-9.

16 Tan CK, Castillo C, So AG, Downey KM. An auxiliary protein for DNA polymerase delta from fetal calf thymus. $\mathcal{f}$ Biol Chem 1986;261:1231-6.

17 Auffermann W, Urquardt M, Rubben $H$, Wohltmann D, Böcking A. DNA grading of urothelial carcinoma of the bladder. Anticancer Res 1986;6:27-32.

18 Granzen B, Auffermann W. Algorithm for a DNA cytophotometric diagnosis and grading of malignancy. Ana Quant Cytol 1984;6:1-8.

19 UICC. TNM classification of malignant tumours. 3rd edn Geneva: UICC, 1978

20 Mostof FK, Sobin LH, Torloni H. Histological typing of urinary bladder tumours. In: International histological classification of tumours. No. 10. Geneva: World Health Organization, 1973.

21 Bacus JW, Grade LJ. Optical microscope system for standardized cell measurements and analyses. Appl Optics 1987; 26:3280-93.

22 Doglioni C, Dei Tos AP, Laurino L, Chiarelli C, Barbareschi $\mathrm{M}$, Viale $\mathrm{G}$. The prevalence of $\mathrm{Bcl}-2$ immunoreactivity in breast carcinomas and its clinicopathological correlates, with particular reference to oestrogen receptor status. Virchows Arch 1994;424:47-51.

23 Levine AJ. The p53 tumor suppressor gene. $N$ Engl f Med 1992;326:1350-2.

24 O'Connor PM, Jackman J, Jondle D, Bhatia K, Magrath I Kohn KW. Role of the p 53 tumor suppressor gene in cell cycle arrest and radiosensitivity of Burkitt's lymphoma cell lines. Cancer Res 1993;53:4776-80.

25 Lipponen PK. Expression of nuclear oncoprotein p53 in transitional cell bladder cancer and its prognostic value. Int $\mathcal{F}$ Cancer 1993;53:365-70.

26 Lipponen PK, Nordling S, Eskelinen MJ, Janhiainen KJ, Terho R, Harju E. Flow cytometry in comparison with mitotic index in predicting disease outcome in transitional mitotic index in predicting disease outcome in trans

27 Lipponen PK, Eskelinen MJ, Janhiainen K, Harju E, Terho $\mathrm{R}$, Haapasalo $\mathrm{H}$. Independent clinical, histological and quantitative prognostic factors in transitional cell bladder tumours, with special reference to mitotic frequency. In f Cancer 1992;51:396-403.

28 Hemstreet GP 3rd, Rollins S, Jones P, Rao JY, Hurst RE, Bonner RB, et al. Identification of a high risk subgroup of grade 1 transitional cell carcinoma using image analysis based deoxyribonucleic acid ploidy analysis of tumor tissue. $₹$ Urol 1991;146:1525-9.

29 Lipponen PK, Aaltomaa S. Apoptosis in bladder cancer as related to standard prognostic factors and prognosis. $f$ Pathol 1994;173:333-9. 